\title{
THE ELEVENTH CONVENTION PROPOSED BY THE HAGUE CONFERENCE OF 1907
}

All progress towards world reform yet accomplished has been made at a slow pace. Only those who forget this are impatient at the outcome of the Hague conference of 1907.

Much of its time was devoted to matters of comparatively small moment. It was wise to have it so. Forty or fifty sovereign powers can hardly come into a position to deal to advantage in legislative fashion with large questions until they have found themselves able to agree on those of less importance. The natural thing therefore happened. Vast changes in international relations, such as would be produced by general arbitration treaties, world prize courts, or fixed limitations of armaments, were civilly mentioned and passed on for future consideration. But, a few projects of that character having thus been gently put aside, a great many projects of minor interest were discussed thoroughly and frankly, and finally placed in such shape as to give promise that they will soon become part of the law of the civilized world.

In this way the last in number of the four commissions, from which was to come the material for the action of the conference, became perhaps the most prolific of results. It was constituted to act in a narrow field. It had nothing to do except with what was related to naval warfare. It had nothing to do with that, except with reference to humanizing it and establishing certain juridical relations which might grow out of it affecting the interests of private individuals.

Let the attention of any small body of men, trained to share in the functions of government, and therefore necessarily familiar with the larger features of law, be concentrated in our day upon the study of the juridical relations arising out of certain facts, and they will, by the very nature of their task, be inclined to agreement. They are considering universal ideas. They are considering them in the 
light of the justice belonging to an advanced civilization. They are interpreting or ascertaining or reframing rules of law; and law in its essence belongs to the realm of the eternal, and is one for all men who are able to see it as it is.

The conference referred seren subjects to the Fourth Commission for investigation. Of these, five were of a kind that intimately concermed the special interests of the leading powers. These wero the seizure of private property of subjects of the enemy at sea, contraband of war, blockade, the destruction of neutral ships at sea, and the general application to sea warfare of the rules already established for warfare on land. It is not surprising that the commission found itself able to do little or nothing in respect to any of them.

The remaining subjects, the transformation of merchant ships into men of war and the treatment of merchant ships of the enemy away from home at the outbreak of war, fared better because the interests of the different powers were in less opposition. The conventions recommended, however (the sixth and seventh, as adopted), were deemed by the delegation from the United States to be steps backward, and their approval was withheld.

This disposition of the business referred to it would have left the work of the Fourth Commission comparatively insignificant had it not been for its taking up additional matters brought before it otherwise than by the original action of the conference and forming no part of the official program prepared by Russia. These took shape in the eleventh convention.

That of most importance to most people is the agreement that correspondence by mail shall be inviolable. Whether official or private, whether pertaining to the conduct of the war or not, letters, though from the enemy, are not to be opened unless the ship bo seized going to or coming from a blockaded port. Reservation is made of the right of visitation and search; but the visit is to be made only when it seems necessary, conducted with all consideration, and closed as quickly as possible.

This is a naiural consequence of the growing unification of the postal systems of the world under the Universal Postal Union, with 
its little world legislature, which has been so long and so usefully in operation. It is also a mark of the progress of scientific invention. Letters carried on shipboard are a slow and cumbrous mode of sending intelligence, when compared with what is offered by methods of electrical transmission. Little was therefore asked in extending the rule of inviolability of postal matter even to enemy's ships bearing enemy's dispatches.

Germany brought this subject before the commission and treated it as an incident of the law of contraband. Herr Kriege presented the views of his delegation in that connection:

Postal relations [he said] have at our epoch such importance - there are so many interests, commercial or other, based on the regular service of the mail - that it is highly desirable to shelter it from the perturbations which might be caused by maritime war. On the other hand, it is hardly probable that the belligerents who control means of telegraphic and radio-telegraphic communication would have recourse to the ordinary use of the mail for official communications as to military operations. The advantage to be drawn by belligerents from the control of the postal service therefore bears no proportion to the prejudicial effect of that control on legitimate commerce. ${ }^{1}$

The German proposal was but slightly modified in the convention as adopted. It did not originally contain the saving as to blockade runners, but the incorporation of that limitation was obviously proper.

The doctrine so vigorously supported by the Supreme Court of the United States in The Paquette Habana ${ }^{2}$ was brought to the notice of the commission by its president, $M$. de Martens, who invited discussion as to the liability of fishing boats to be seized as prize, by special reference to it in a questionnaire which he sent out to its members.

The presiding officer of any deliberative body has in Europe even greater opportunities of influence and control than belong to such a position in the United States. Mr. de Martens, as president of the Fourth Commission, used his initiative with great effect. He also

I See a discussion of this subject in Hershey's International Law and Diplamacy of the Russo-Japanese War, p. 153 et seq.

2175 U. S. 677. 
gave, on many occasions, a turn to the direction of discussion which proved decisive. 'In summing up a debate, before putting the question, he had the art of letting the full weight of his own opinion be felt, without declaring it, though occasionally speaking out with great plainness. In closing the discussion on the proposal to affirm the inviolability of all private property at sea, to support which a quotation from one of his own works had been read, he observed that he had indeed so expressed himself forty years ago; " he was then by conviction a partisan of the rule of inviolability, but that since that distant epoch he had become more circumspect regarding this delicate question." A vote having been taken, showing twenty powers in favor of the proposal to eleven (including Russia) in opposition and one not participating, he remarked that in view of the populations of the powers voting against it, and their naval strength, the result hardly possessed the value of a decisive indication of international sentiment. ${ }^{3}$

The proposed exemption of fishing boats received its first definite form at the hands of Portugal. Her delegation (annexe 45) suggested that it be confined to boats in the territorial waters of the country, or in the usual fishing zone off its coasts. Mindful of the Dogger Bank incident, they added a prohibition of approach by the boats near to men of war of the enemy. Large fishing vessels, destined for distant royages, were to be subjects of prize.

Austria-Hungary presented a more liberal scheme. This (annexe 43) included any small craft found in territorial waters engaged in "économie rurale," or petty local traffic. They might, however, be seized if needed for military use, but in such case the owners were to be indeinnified.

Norway proposed that the indemnity should cover the value of the boat and 10 per cent. additional; this to be paid over at the time of seizure, if possible.

The Italian delegation now called attention to a provision in their code by which the ships of a belligerent employed on a purely scientific mission might remain in Italian ports as long as they chose, and advocated an extension of the proposed exemption of fishing 3 Session of July 17. 
craft to all vessels employed in scientific or humanitarian voyages. From France came the suggestion that voyages for religious and missionary purposes should be included.

The provisions finally adopted showed that humanitarian rather than military considerations controlled the commission. The feeling may be said to have been universal that wherever the range of war could be contracted in these directions, without serious interference with military necessities, it should be. The somewhat ambiguous phrase, "rural economy," was thus replaced by "services of petty local navigation;" and, contrary to the repeated insistence of the president, the exemption was made seemingly applicable to vessels moved by steam or other mechanical power.

No attempt was made to define how far coast fishing might extend beyond strictly territorial waters.

The provisions in the eleventh convention as to the fate of crews of captured merchantmen of the enemy were brought before the commission by Great Britain and Belgium. Their adoption constitutes a long step in advancing the interests of commerce. They take the crews out of the position of prisoners of war; release them entirely, if they are not enemies; and, if they are, release them on parole, to be evidenced by their written promise. The authorities of the enemy are to be notified of the names of those paroled, and are forbidden knowingly to employ them thereafter in military operations during the continuance of the war.

The discussion of this feature of the convention occupied much of the time of the commission during several sessions. It was fully recognized as a wide departure from the laws of war, as heretofore existing. ${ }^{4}$ On the other hand, the vast proportions of modern international trade were felt to demand a new measure of protection, in the common interest of mankind.

That the field of war is likely to be narrower at the three points covered by this convention must be pronounced a gain to humanity. The general ratification of the eleventh convention would be a permanent extension of the bounds of peace. The prospect of such

4 See, e. $g$, the conventions between Great Britain and France of 1854 and 1860, quoted in Atherly-Jones on Commerce in War, p. 584. 
a ratification seems fair in view of the fact that each of the three articles was adopted by the conference without a single negative vote. Nicaragua and Paraguay, however, took no part in these votes, and the Argentine Republic formally abstained from voting on that establishing the inviolability of the postal service.

Simeon E. Batdwin. 